\title{
LESPORT COM A INSTRUMENT REFORÇADOR DEL SENTIMENT NACIONAL. LES IMPLICACIONS DELS TRIOMFS DE LA SELECCIÓ ESPANYOLA DE FUTBOL EN EL DISCURS DE LA MILITÀNCIA VALENCIANA D'ESQUERRA I CENTREESQUERRA \\ THE SPORT AS A REINFORCER INSTRUMENT OF THE NATIONAL FEELING. THE IMPLICATIONS OF THE SPANISH FOOTBALL NATIONAL-TEAM TRIUMPHS IN THE DISCOURSE OF LEFT-WING AND CENTRE-LEFT-WING VALENCIAN MILITANTS
}

\author{
Lluís Català Oltra \\ Dep. Sociologia II. Universitat d'Alacant. Espanya \\ luis.catala@ua.es
}

\begin{abstract}
Resum
En aquest treball es repassa primerament el paper que ha tingut l'esport en el reforçament de la identitat nacional. A continuació, centrem l'atenció en el futbol per a parlar de la dinàmica centre-perifèria duta al terreny dels clubs de la Lliga espanyola; i dels èxits de la selecció espanyola i les implicacions per al sentiment nacional. Això últim ens serveix de base per a l'estudi empíric desenvolupat a partir d'entrevistes semiestructurades a militants de base de partits valencians d'esquerra i centreesquerra. Amb aquest material analitzem els discursos dels militants sobre aquestes victòries i la seua relació amb la identitat nacional.

Paraules clau: nacionalisme, nació, esport, futbol, partits polítics, identitat, Espanya
\end{abstract}

\section{Abstract}

In this work firstly we review the role played by the sport in the reinforcement of national identity. Next, we focus on the football, to talk about the centre-periphery dynamic brought to the terrain of Spanish League clubs; and about the successes of the Spanish national team and their implications for the national feeling. This last serves us as a base for the empirical study developed from semistructured interviews to militants of left-wing and centre-left-wing 
Valencian parties. With this material we analyse the discourses of the militants about these victories and their relation with national identity.

Keywords: nationalism, nation, sport, football, political parties, identity, Spain.

\section{NACIONALISME, FEIXISME, MITJANS DE COMUNICACIÓ DE MASSES... I EN AIXÒ, L'ESPORT}

Segons Anderson, després de la Segona Guerra Mundial, la nació estat arriba al seu zenit i es trasllada definitivament a les antigues colònies d'África i Àsia; és el moment en què la nació cobra tot el seu sentit -modern- (Anderson, 1993: 161). A partir de llavors, el dret d'autodeterminació passaria a formar part del vocabulari habitual de les relacions internacionals (Hobsbawm, 1992: 146) i es globalitzaria vertaderament el nacionalisme. Per tant, aquest podria ser l'inici de la nació moderna i tot el període anterior des del 1789 fins a l'actualitat els «antecedents moderns». Hobsbawm va més enllà quan, respecte d'aquesta època, parla de la consolidació dels mitjans de comunicació de masses, que van ser capaços de «fer que els símbols nacionals passaren a formar part de la vida de tots els individus, trencant així les divisions entre les esferes privades/locals, en les quals vivia normalment la majoria dels ciutadans, i l'esfera pública/nacional» (1992: 151).

I una de les representacions més clares de l'efecte dels mitjans de comunicació va ser la transformació de l'esport com a espectacle de masses, que d'aquesta manera va guanyar protagonisme com a expressió de lluita nacional, ja que es van promoure nombroses competicions entre estats o nacions. Com apunta Eric Hobsbawm encertadament, a partir dels anys 20, l'esport, com a espectacle de masses, es converteix «en una inacabable successió d'encontres de gladiadors protagonitzats per persones i equips que simbolitzaven estats nació, cosa que actualment forma part de la vida mundial» (1992: 152). Es consolidava un model de competicions entre «els d'ací» i «els d'allí», que té la seua arrel moderna en els segles XVIII i XIX (per exemple les carreres i campionats entre Òxford i Cambridge), però que té orígens més ancestrals en les competicions entre clans a Escòcia o entre caserius al País Basc; en la tradició grecoromana que va oferir els jocs olímpics, les carreres de quadrigues, o les lluites al circ; o, més recentment, també en els tornejos medievals o el calcio florentí, considerat un dels precursors del futbol modern.

Ara, el nou olimpisme del baró de Coubertin (i més encara a partir dels Jocs prebèl-lics de Berlín el 1936), el Tour de França (amb seleccions nacionals inicialment) o els mundials de futbol (iniciats el 1930 a l'Uruguai) serien esdeveniments que començaven a representar un terreny de disputa nacional amb dos propòsits fonamentals: atenuar les tensions internacionals (combat a mort substi- 
tuit per una pugna amb normes i suposadament sense conseqüències finals) i incrementar la identificació amb la nació, perquè, encara segons Hobsbawm, «la comunitat imaginada de milions d'individus sembla més real sota la forma d'un equip d'onze persones amb uns noms que tots coneixem. Lindividu, fins i tot el que es limita a animar el seu equip, passa a ser un símbol de la seua nació» (1992: 152-153; vegeu també Arnaud, 1991: 182-194; Bairner, 2001; Payero, 2009: 94). La capacitat de síntesi de l'esport i el seu magnetisme (molts homes voldrien tenir les capacitats dels millors esportistes que són els que donen contingut a l'espectacle) van accelerar el procés d'identificació de la població amb les seues nacions.

Extremadament, el feixisme italià i el nacionalsocialisme alemany havien sigut precursors en l'ús polític (i nacional) dels esdeveniments esportius (que començaven a convertir-se en massius precisament aleshores), sobretot a partir de la Segona Copa Mundial de Futbol disputada a Itàlia el 1934 (amb triomf final de l'amfitriona per a satisfacció de Mussolini i el seu aparell de propaganda) i els Jocs Olímpics de Berlín el 1936, amb una exhibició de símbols i una posada en escena fins a aquell moment inèdita (Hobsbawm, 1992: 152-153) sota el lideratge de Goebbels i la col-laboració de la cineasta Leni Riefenstahl, precursora de les actuals cobertures televisives d'aquests actes, i l'arquitecte de la megalomania oficial, Albert Speer (Young, 2005: 29-30). El franquisme també es recolzarà en l'esport per a exaltar la nació i són ben recordades la victòria d'Espanya enfront d’Anglaterra («la pérfida Albión»), amb el clímax del gol de Zarra, el triomf de la selecció nacional espanyola de futbol en la final de l'Eurocopa del 1964 celebrada a Espanya, els èxits europeus del Reial Madrid (Colomé, 2007: 379), o les gestes de Bahamontes en el Tour, i la lectura en clau d'èpica i heroïcitat nacionals. També podríem afegir la utilització propagandística de la Copa Mundial de Futbol del 1978 per part de la Junta Militar d'Argentina, i molts altres casos arreu del món durant el segle xx. En definitiva, l'ús que el feixisme li va donar a l'esport a partir dels anys trenta ha calat tant en la modernitat tardana que s'ha assentat de manera permanent en les nostres societats, independentment del tipus de règim o del signe polític dels governants.

Estem ja en un moment d'esplendor del «principi de nacionalitat» (Gellner, 1998: 51) i l'esport podia contribuir a alleujar tensions, però sobretot hi havia la possibilitat d'incrementar l'adhesió a la nació, la identificació amb ella a través d'aquesta síntesi que constituien uns quants esportistes que tothom va reconeixent i que, així, ni tan sols cal imaginar -són membres de la comunitat nacional dels quals sí que tenim constància-, no com de la resta dels connacionals que no estan en el nostre àmbit de relacions, i per tant, com deia Anderson (1992), hem d'imaginar que formen part de la comunitat, de la nació. En la mateixa línia, Maguire sosté que: 
L'esport representa diferents individus, comunitats, regions i nacions, i una característica clau del procés de formació de l'esport global és que l'usen diferents grups -aquells que estan més consolidats, com també grups socials emergents o marginals- per a representar, mantenir i desafiar les identitats (1999: 176; citat en Sopena i al., 2008; vegeu també Finn \& Giulianotti, 2000: 256; Medina, 2009: 3).

En aquest escrit, volem fer una aproximació actualitzada a aquesta qüestió en el context de la dinàmica centre-perifèria, entesa com la relació entre el centre i la perifèria estatals en la pugna per imposar o fer visible el seu projecte nacional, normalment oposat l'un a l'altre i amb cadenes associades d'acció-reacció (Letamendia, 2007). Tot i que farem al.lusió a altres esports, ens centrarem en el futbol, que és l'esport de masses per excel-lència a l'estat espanyol i el que, en bona part per això, és capaç de mobilitzar les majors adhesions nacionals. Després de les referències a la dinàmica centre-perifèria (que, a l'estat espanyol, són necessàries per a entendre quina és l'alternativa nacional esportiva per als que no se senten espanyols), centrarem l'atenció en les implicacions «nacionals» dels triomfs de la selecció espanyola de futbol i, finalment, en la part empírica, en les reflexions que fa sobre aquestes victòries la militància valenciana d'esquerra i centreesquerra en el context d'una investigació sobre identitat territorial. En aquest propòsit, ens referirem al «sentiment nacional» com l'afecte envers la nació o, com suggereixen Dekker i al., el «sentiment de pertinença al propi poble o país» (2003: 347), normalment mesurat en els estudis quantitatius a través de preguntes senzilles com ara «Se sent vostè espanyol?»o «En quina mesura se sent vostè espanyol? ${ }^{1}$, però que aquí es plantejarà lligat al futbol com a fenomen de masses en el sentit de si determinats èxits de l'equip nacional espanyol poden haver contribuit a provocar «l'orgull de parells», l'alegria pel fet que es tracta de connacionals i això implica que, en certa mesura, la victòria és de tots, perquè aquesta s'ha produit en nom d'Espanya, i tots en som membres. També ens referirem a la «identitat nacional»com un sentiment de pertinença compartit pels membres de la nació, partint d'alguns trets distintius objectius (llengua, història, costums, institucions, etc.), que han de ser presos en consideració de manera significativa per aquests subjectes i han de permetre la constitució d'un sistema de delimitació en el qual hi ha autodefinició, però també distinció respecte d'altres nacions. A partir d'aquí i sobre una mínima estabilitat que permet als connacionals reconèixer la identitat tot i el pas del temps, aquesta es reformula contínuament (encara que no són habituals els canvis sobtats).

\footnotetext{
${ }^{1}$ Vegeu, per exemple, els Baròmetres autonòmics del CIS o els Eurobaròmetres de la Comissió Europea.
} 
Laproximació a les reflexions de la militància valenciana d'esquerra i centreesquerra sobre els triomfs de la selecció espanyola se'ns ha revelat crucial per a acabar d'entendre quin és el seu discurs identitari, especialment si considerem la seua complexitat, amb la interacció de diferents identitats territorials i marcs nacionals $i$, en conseqüència, diferents combinacions d'identitats duals ('espanyol' i 'valencià', 'valencià' i 'català'; vegeu Coller i Castelló, 1999). Addicionalment, la resistència a acceptar el vincle explícit amb la nació espanyola per part de la militància d'esquerra pels anys de dictadura franquista (Núñez, 2007: 159) fa especialment útils aquests abordatges indirectes, que aporten els matisos necessaris per a entendre que, tot i que «banalment» (Billig, 2006), els vincles nacionals amb Espanya es produeixen entre part de l'esquerra valenciana.

\section{MÉS QUE UNS CLUBS: LA LLIGA COM A ESCENARI DE LA DINÀMICA CENTRE-PERIFÈRIA}

Als camps de futbol és molt habitual veure banderes, tot i que la normativa que impedeix entrar pals ha disminuit aquesta presència. Hem pogut observar que aquestes banderes no són únicament dels equips en lliça, sinó també, de manera freqüent i almenys en els terrenys de joc de la Lliga espanyola ${ }^{2}$, de les seues regions i nacions de procedència. Pràcticament totes les aficions tenen una afiliació nacional que combinen amb els colors de l'equip. Així, a San Mamés, l'estadi de l'Athletic Club de Bilbao, no es veuen només banderes roig-i-blanques (colors del club), sinó també la tricolor basca, la ikurriña; i al Camp Nou, els colors blaugrana solen combinar-se amb la quadribarrada catalana, la senyera. Les penyes anomenades ultres o radicals (i moltes de les no tan radicals) dels equips han tingut en la qüestió nacional un dels seus fonaments $i$, moltes vegades, el marc de representació del seu maximalisme. En els territoris on més assentats estan els nacionalismes subestatals, Catalunya i el País Basc, la vinculació nacional és, pràcticament sense excepcions, la perifèrica. Així passa des de fa temps amb l'esmentat Athletic Club de Bilbao (intensificat en aquest cas per una política etnoterritorial de formació del planter), amb la Real Sociedad de Sant Sebastià, el Deportivo Alaves o l'Atlético Osasuna de Pamplona, si parlem d'Euskal Herria; o amb el Barça, Gimnàstic de Tarragona, Unió Esportiva Lleida o Girona a Catalunya (Díaz Noci, 2000; Llopis, 2007)³.

\footnotetext{
${ }^{2}$ Però no únicament, com s'arreplega en Seco (2011) per al cas escocès, Rogers i Rookwood (2007) per al cas gal-lès, o Szabó (2012) per al cors.

${ }^{3}$ El cas del RCD Espanyol seria una mica excepcional perquè en l'estadi s'han vist algunes banderes catalanes, però la penya ultra Brigadas Blanquiazules sol combinar els colors del club amb la bandera d'Espanya, en part com a contrast amb el catalanisme del Barça.
} 
A la resta de l'estat, depèn molt si les penyes són d'orientació dretana o esquerrana i, així, l'observació ens diu que, com a norma general, les de dretes solen combinar amb banderes d'Espanya; i les d'esquerres, o no utilitzen cap bandera nacional o agafen la de la comunitat autònoma o nació subestatal (vegeu també Adán, 2004: 96-97). Per exemple, les penyes ultres del Real Betis Balompié (de Sevilla) són més aviat de dretes i per això no és estrany veure banderes d'Espanya a l'estadi Benito Villamarín. Mentre que les penyes del Sevilla FC, més aviat d'esquerres, o no utilitzen cap bandera o utilitzen les d'Andalusia (de tota manera, ha anat perdent-se l'ús perquè implica afegir a l'estampa roig-i-blanca de l'afició sevillista els colors del rival, el Betis, que, com la bandera d'Andalusia, vesteix verd-i-blanc). Es produeix, doncs, aquesta alineació política esquerra-nacionalisme subestatal i dreta-nacionalisme espanyol, que denuncien personatges com el periodista César Alonso de los Ríos o el polític José Bono, per esmentar-ne alguns dels que més hi insisteixen ${ }^{4}$.

La filiació nacional dels equips reforça la simbologia i la identitat grupal de cara als enfrontaments contra equips amb aficions que tenen una altra filiació nacional. Així, els aficionats de l'Athletic Club de Bilbao o del Barça paren més atenció en la simbologia nacional basca/catalana quan el rival és el Reial Madrid, club aquest amb una afició que sol combinar els colors madridistes amb banderes d'Espanya i que és la més viva representació del centre espanyol en el món del futbol. També els madridistes posen més èmfasi en la simbologia nacional espanyola $\mathrm{i}$ en determinades arengues antibasques o anticatalanes quan arriben equips d'aquelles terres, reproduint la dinàmica centre-perifèria. Sota aquesta perspectiva, per exemple, una victòria del Barça sobre el Reial Madrid és una victòria de Catalunya sobre Espanya.

Alineacions o associacions nacionals d'equips com el FC Barcelona o l'Athletic Club de Bilbao, que es produeixen des del franquisme (vegeu Santacana, 2005; Naranjo, 2011: 133) i també abans (Llopis, 2006: 43-44; Shobe, 2008), i que fins i tot han sigut promocionades pels dirigents dels clubs (el cas més clar és el del mandat de l'expresident Joan Laporta, que després ha sigut diputat nacionalista, i que va fer incloure la bandera catalana en la samarreta de l'equip $)^{5}$, vénen a suplir l'absència d'una selecció nacional que puga compe-

${ }^{4}$ En el cas de César Alonso, vegeu, per exemple, el seu assaig La izquierda y la nación. Una traición políticamente correcta, Ed. Planeta, 1999. I en el de José Bono, l'entrevista en el programa En días como hoy, dirigit per Juan Ramón Lucas a RNE, el día 2 de desembre de 2011; recuperat a: http://www.rtve.es/alacarta/rne/

${ }^{5}$ Des de fa temps, però, el braçalet de capità del Barça és la bandera de Catalunya, el de l'Athletic Club de Bilbao o la Reial Sociedad la ikurriña, etc. 
tir internacionalment al mateix nivell que l'espanyola. Des de la transició, Catalunya i el País Basc, tenen selecció «nacional» de futbol que sol jugar un amistós per les vacances del Nadal (després també han sorgit les seleccions autonòmiques de la resta de territoris). Però, tot i les demandes per part de determinats grups polítics catalans i bascos, no han pogut passar a l'oficialitat, a jugar en les classificacions per a competicions mundials i europees ${ }^{6}$, com fan en molts esports les diferents seleccions «nacionals» del Regne Unit (Escòcia, Gal.les, Irlanda del Nord i Anglaterra) $)^{7}$. Mentre això no es produïsca, els equips catalans i bascos, i molt especialment l'Athletic Club de Bilbao o el FC Barcelona, arrepleguen aquesta «necessitat» d'identificació nacional en el futbol i, d'aquesta manera, com deia Hobsbawm (1992: 152), els onze jugadors són la representació de tot un poble, de les nacions catalana o basca, que s'enfronta als representants de la nació espanyola (normalment el Reial Madrid, que és l'equip que, com hem dit, millor simbolitza el centre). No debades, més de la meitat dels catalans identifiquen el FC Barcelona amb la idea (nacional) de Catalunya (Llopis, 2006: 54). I cal esperar, avançant-nos a la part empírica, que aquells valencians que fan seu el marc nacional dels Països Catalans pensen d'una manera semblant.

\section{3. «L'EDAT D'OR» DE L'ESPORT ESPANYOL I LA CULMINACIÓ DE LA ROJA FUTBOLÍSTICA: NOVES PERSPECTIVES PER AL SENTIMENT NACIONAL ESPANYOL}

Mentre això succeeix, ja en els noranta, però sobretot a partir del nou mil.lenni, es viu el que els mitjans de comunicació han anomenat «l'edat d'or de l'esport espanyol», amb importants triomfs internacionals en diferents modalitats, i fins i tot dominadors mundials en determinades disciplines, com és el cas en alguns moments d'Alberto Contador en ciclisme, Fernando Alonso en automobilisme, Rafael Nadal i l'equip de Copa Davis en tennis, els motociclistes encapçalats per Jorge Lorenzo i Marc Márquez, les seleccions nacionals de

\footnotetext{
${ }^{6}$ En l'hoquei patins hi va haver una excepció temporal, quan la Federació Internacional de Patinatge-FIRS va reconèixer la Federació Catalana i aquesta va participar en el Campionat del Món B, que va guanyar amb claredat. Les protestes d'Espanya culminaren amb la retirada d'aquest reconeixement i la prohibició de participar en competicions de la FIRS. D'altra banda, Catalunya està reconeguda oficialment per les federacions internacionals d'esports minoritaris com el futbol australià, escalada o kick-boxing.

${ }^{7}$ Són molts els esports d'equip que han iniciat els britànics (futbol, rugbi, criquet, hoquei, etc.) i, quan encara eren disciplines només practicades a les illes, els enfrontaments entre les diferents nacionalitats eren habituals i això va acabar generant federacions pròpies, que, una vegada difosos els esports a la resta del món, ja estaven massa arrelades per a desfer-les i es va acceptar la seua participació separada.
} 
basquetbol, handbol, hoquei patins, futbol sala, etc. ${ }^{8}$. Aquests esportistes pertanyen a una generació que temporalment té molt lluny el franquisme i els prejudicis de la transició respecte de la nació espanyola i la bandera ${ }^{9}$, i no tenen cap problema a l'hora d'apel-lar a l'esperit nacional com a inspiració per al triomf, o celebrar les victòries amb una bandera espanyola o emocionar-se escoltant l'himne nacional, perquè ho han vist des de joves amb competidors d'altres paisos i no troben motius per a no actuar d'una manera semblant. L'equip de la Copa Davis és un clar exemple del que apuntem, com expressa un article de l'ABC: «Nadal és l'ambaixador de la marca Espanya, perquè ningú defensa millor que ell la bandera» ${ }^{10}$. Les generacions joves d'espanyols, que tampoc estan socialitzades en el franquisme i ho estan molt poc en els prejudicis que en pogueren quedar durant la llarga transició, reforcen el seu sentiment patriòtic a través d'aquests herois populars, tot i que estem en una fase de transnacionalització de l'esport i transformació creixent de les activitats esportives en negocis que funcionen a partir de criteris de rendibilitat (Robertson \& Giulianiotti, 2006; González-Ramallal, 2008: 223).

I en la punta de llança de tot això, faltaven els triomfs de la selecció espanyola de futbol, que són els que estimulen la majoria de la gent, perquè és,

\footnotetext{
${ }^{8}$ Aquests èxits, sobretot en esports en què es mouen prou diners, contrasta amb la discreció dels resultats en disciplines com atletisme, natació, esports d'hivern, gimnàstica, etc., que són els que proporcionen la major quantitat de medalles en els Jocs Olímpics, en els quals Espanya ocupa un lloc no capdavanter en el medaller. Això deixa clar que la concepció de l'esport com una indústria o com un aparador per a la promoció empresarial, dominant arreu del món, té a Espanya un dels seus pilars.

${ }^{9}$ Com a exemple ben il.lustratiu del que comentem, quan Espanya guanya l'Eurocopa 2008 i els jugadors estan oferint el triomf als aficionats a la plaça de Colón, el davanter David Villa va cridar eufòricament l'arenga «iArriba España!», de reminiscències franquistes. El periodista català Enric Hernández (aleshores en El País) comentava en la tertúlia del programa En días como hoy de RNE el dia 1 de juliol de 2008 que és un signe de normalitat, que el llenguatge es pot utilitzar sense temor, sense vincles a determinades concepcions polítiques. Però també es pot interpretar com un símptoma de pèrdua de memòria, de pas generacional, d'arribada d'unes generacions a les quals els queda lluny la dictadura. També comenta Enric Hernández com a símptoma de normalitat el fet que Xavi Hernández, català, cridara també « ¡Viva España!»; però això no ho van fer altres com Carles Puyol o Cesc Fàbregas, o el 2010 Gerard Piqué, per exemple, que van exhibir banderes catalanes durant les celebracions (Cesc F. fins i tot ha lluit l'estelada en celebracions del Barça). Cas a banda és el d'Oleguer Presas, convocat una vegada amb la selecció de Luis Aragonés (va acudir després de molts dubtes) i que s'ha declarat independentista català. Com apunta Lucía Payero (2009: 89), no s'ha d'obviar que les possibilitats de prestigi i de lucre les proporciona la selecció espanyola, la reconeguda internacionalment i, així, altres consideracions, com el sentiment nacional, poden quedar al marge.

${ }^{10}$ Enrique YUNTA, «Nadal, el héroe de la mejor quinta», a ABC.es, 5/12/2011 (http:// www.abc.es/20111204/deportes-tenis/abci-nadal-orgullo-espana-201112041705.html, visita el 15/11/2013).
} 
amb diferència, l'esport més seguit a l'estat. Superat el fatalisme de caure en les rondes decisives, Espanya, una de les potències teòriques del futbol mundial, però que mai materialitzava el seu potencial, arriba a la final de l'Eurocopa d'Àustria-Suïssa 2008 i la guanya exhibint un joc admirat per aficionats i especialistes ${ }^{11}$. L'eufòria col-lectiva d'un país ja sumit en els primers trams de la gran crisi es va desbordar com no havia succeit mai en la història de l'esport espanyol, i una de les grans novetats d'aquesta celebració va ser l'ús massiu de la bandera d'Espanya. Ja quan es passa la barrera psicològica dels quarts de final davant d'Itàlia, en certa mesura es considera un triomf i comencen a veure's més banderes del que era habitual en cotxes, façanes, bars, llocs de treball, etc., i també les samarretes de la selecció van formant part del paisatge de pobles i ciutats en aquell mes de juny. En part per l'escassa confiança en la capacitat de la selecció, però sobretot per la manca de precedents d'una eufòria nacional d'aquestes característiques, els fabricants i distribuidors de banderes van esgotar les existències i van estar col-locant tota la seua producció fins i tot setmanes després de la final. Molts balcons de les localitats de tot Espanya van estar durant un temps engalanats amb la bandera bicolor. El paper dels mitjans de comunicació del centre en aquest comportament de masses va ser decisiu, en molts casos fins i tot fent crides a l'orgull nacional i a l'exhibició dels símbols. I també donant gran difusió a la consigna del seleccionador nacional d'aleshores Luis Aragonés, que va rebatejar l'equip d'Espanya amb l'apel-latiu de la roja (a imitació del brasiler la canarinha, l'italià esquadra azzurra, el francès els bleus, o l'argentí l'albiceleste; és a dir, a imitació de les grans potències, guanyadores de mundials $)^{12}$.

Tot i el precedent europeu i la definitiva incorporació dels establiments xinesos a l'oferta de productes nacionals, quan les expectatives es tornen a complir en la Copa Mundial de Futbol de Sudàfrica 2010, les tendes tornen a esgotar existències $^{13}$, perquè l'exemple de 2008 desinhibeix molts d'aquells que senten l'esperit nacional i no havien fet el pas d'exhibir-lo durant l'Eurocopa. És a dir, l'exhibició nacional agafa una magnitud encara més gran, en part perquè l'ob-

${ }^{11}$ Un joc, d'altra banda, clarament influït per la filosofia del FC Barcelona, que és una qüestió que, com veurem, ha sigut observada diverses vegades en el treball de camp, sobretot com a justificació de l'adhesió a la selecció per part de culés que no se senten espanyols.

${ }^{12}$ Els èxits internacionals han contribuitt a consolidar l'apel-latiu la Roja fora de les fronteres estatals, com demostra l'article del Wall Street Journal a càrrec de Matthew Futterman, «Is Spain's "la Roja" the greatest team ever?» (edició digital del Wall Street Journal, 7/6/2012, vegeu http://online.wsj.com/article/SB10001424052702303918204577448383166444226. html, visita el 15/11/2013).

${ }^{13}$ María José DE FEZ, «La euforia por la selección dispara la venta de banderas nacionales», a Las Provincias, 9/7/2010. 
tenció de la Copa del Món sí que era una gran llacuna en el palmarès esportiu espanyol (ja s'havia obtingut una Eurocopa el llunyà 1964, però mai s'havia arribat ni tan sols a una final d'un Mundial), que per fi semblava possible esborrar, i de fet, es va aconseguir. Centenars de milers de persones a tot l'estat cridaven en les places una de les tornades que més de moda s'han posat des d'aleshores cada vegada que Espanya juga alguna competició en qualsevol esport: «iYo soy español, español, español», curiosament amb els acords de la cançó popular russa Kalinka. En definitiva, el que ni polítics, ni intel-lectuals, ni opinadors espanyols havien aconseguit en més de trenta anys de democràcia, normalitzar el fet nacional espanyol i els seus símbols, ho havien obtingut uns joves que, amb tots els respectes, guanyen milions d'euros pegant puntades de peu a un baló.

Com ja van fer el 2008, els mitjans de comunicació del centre celebraven la victòria esportiva i el joc de la selecció (potser ja no tan brillant com aleshores), però també les implicacions sobre l'esperit nacional. Servisca com a exemple els articles d'opinió apareguts en el diari $A B C$ els dos dies següents a la victòria en l'Eurocopa 2008 (que és la que obri aquesta fase d'«eufòria nacional») molt centrats en el partit i en aquestes implicacions «nacionals»:

Quizá sería buena idea nombrar al fútbol de la selección española Fiesta Nacional, porque agrupa, bajo la misma bandera y el mismo grito, a todos los españoles. [...] Hacía mucho tiempo que no escuchaba el nombre de España, feliz bajo la misma bandera, sonando, sin complejos, en la voz de muchos millones de españoles. (Antonio García Barbeito, «La fiesta nacional», a ABC.es, 1/7/2008).

[Larticle està dirigit a un jove anònim que celebrava la victòria embolcallat en una bandera d'Espanya] Has visto desde aquí arriba chispear un flash que acaso mañana retrate en los periódicos tu rostro exultante abierto en un grito triunfal, enardecido, jubiloso, que no es de patriotismo ni de política, de nacionalismo ni de ideología, sino de orgullo, de regocijo, de identidad vacunada de prejuicios y de exclusiones. Un grito coral que te hace sentir pleno, acompañado y unánime cuando pronuncias la palabra España con la naturalidad de una emoción y el desacomplejado y comunitario alborozo de una pertenencia (Ignacio Camacho, «El chico de la bandera», a ABC.es, 1/7/2008). No recordamos tantas banderas nacionales abrazadas y exhibidas orgullosamente por un grupo de jóvenes que son una referencia vital para todos los chi$\cos$ y chicas españoles. Sin complejos, con la naturalidad de una generación que no está contaminada por las querellas y las heridas de sus mayores (Edurne Uriarte, «España Txapeldun», a ABC.es, 1/7/2008).

Hemos necesitado que once españoles en calzoncillos se pongan tibios a meter goles para descubrir que el amor a la patria no es pasión vergonzosa ni asque- 
rosita, ni querencia propia de carcas o nostálgicos, ni parecidas zarandajas, sino amor actuante y salutífero, como lo es el amor a la propia sangre. Porque los carcas, y los nostálgicos, y los tíos que dan asquito y vergüenza son los que no lo sienten; los otros, nosotros, tan sólo somos gente normal, esto es, personas que saben dejar a un lado las nimias mezquindades que los separan para abrazarse en nombre de la grandeza que los une (Juan Manuel de Prada, «Al calor de los goles de España», a ABC.es, 30/6/2008).

La selección ha conseguido convertirse en estas semanas en un auténtico fenómeno sociológico. [...] El orgullo de millones de ciudadanos de exhibir sin ridículos complejos ni absurdos pudores su condición de españoles y su orgullo por la bandera nacional y por el escudo constitucional que los jugadores lucen en el pecho. Miles de familias en toda España han colgado en sus balcones banderas rojigualdas como muestra de sincera identificación con la selección y sus metas deportivas o, más sencillamente, con la idea de España como una gran nación, como una gran potencia deportiva en el mundo. (Editorial «Enhorabuena España», a ABC.es, 30/6/2008).

Com ja comentàvem, se celebra l'arribada d'una generació sense complexos respecte de la nació i el retorn del símbol nacional ${ }^{14}$, una ensenya que ja no està lligada al passat franquista (Plaza, 2009). I això s'acompanya de referències a l'emoció que provoca Espanya, a la seua grandesa o fins i tot a la «sang» (vegeu el paràgraf de l'escriptor Juan Manuel de Prada). En definitiva, els opinadors del nacionalisme espanyol estan d'acord en la important contribució dels Casillas, Xavi, Puyol, Iniesta, Villa, Ramos, etc. a l'enfortiment del sentiment nacional, i això ha tingut l'oportunitat d'acabar normalitzant-se amb el nou triomf de la selecció en l'Eurocopa de Polònia-Ucraïna el 2012.

Els diaris esportius madrilenys (As i Marca) també han establit molt habitualment, i més en aquests moments victoriosos, el vincle entre esport i nació (per exemple, Marca.com deia en la seua editorial l'endemà de la consecució de la Copa Mundial de Futbol que «el poble va estar més unit que mai al voltant d'una idea: Espanya») ${ }^{15}$. I el recurs a la història i als mites espanyols són freqüents, com el moment en què van comparar (tant Marca com As) Pau Gasol amb el Cid Campeador quan va ser l'artífex de l'accés d'Espanya a la final del Mundial de Bàsquet del Japó 2006 jugant lesionat. Quan es va saber que no

${ }^{14}$ No s'ha d'oblidar que la bandera nacional, a banda de la seua missió senyalitzadora té una altra de simbòlica, en la qual es representa el «caràcter sagrat de la nació» (Payero, 2009: 112).

${ }^{15}$ Com a exemple recent d'aquestes lectures en clau nacional en els diaris esportius, el mateix dia que Espanya va demanar el rescat per a la banca a una UE liderada per Alemanya (9/6/2012), es jugava l'Alemanya-Portugal de l'Eurocopa 2012 de Polònia/Ucraina, amb resultat final d'Alemanya 1 - Portugal 0 gràcies al gol de Mario Gómez, alemany d'origen espanyol. El titular de Marca de l'endemà era «Un "espanyol" rescata a Alemania». 
podria jugar la final contra Grècia, es parlava que havia de produir el mateix efecte que el Cid en l'adversari -la seua sola presència inspirava temor en els rivals-. El tractament que fan els diaris esportius de Barcelona (Sport i Mundo Deportivo) és ben diferent, en tant que ja d'entrada fugen de la paraula «nació» per a referir-se a Espanya, solen fer al-lusió a l'origen subestatal dels jugadors quan els esmenten -el manxec Iniesta, els catalans Xavi, Piqué, Cesc i Puyol, el canari Pedrito, etc.- (Sopena i al., 2008) i els titulars sobre la selecció solen fer referència als jugadors blaugranes (González-Ramallal, 2008: 228).

Després d'aquestes victòries, els dirigents de la Federació Espanyola de Futbol van tenir clar que ja no hi havia cap rebuig a la bandera i que era l'hora de consolidar el seu paper com a símbol. Això implicava protegir-la de les confusions que es pogueren crear amb altres símbols (els jugadors catalans, per exemple, solen celebrar les victòries d'Espanya embolcallats en una senyera catalana). D'aquesta manera, en el reglament de les seleccions espanyoles es va incloure que no es podia utilitzar cap bandera que no fóra l'espanyola abans i durant la cerimònia de lliurament de guardons en qualsevol competició oficial. Es volia evitar que la imatge d'entrega de la copa, que dóna la volta al món, estiguera enterbolida per la presència de colors diferents dels espanyols, com havia succeit més d'una vegada i com no succeeix en pràcticament cap país. Poc després d'iniciada aquesta norma, Espanya continuava la seua reeixida línia en les seleccions de joves, i guanyava els campionats d'Europa sub-19 i sub-21 l'estiu del 2011. En la cerimònia de lliurament de la copa en la categoria sub-19, el jugador de l'Sporting de Gijón Juan Muñiz apareixia embolcallat amb una bandera d'Astúries. De sobte, davant de totes les càmeres i els presents, el seleccionador Ginés Meléndez va anar cap a aquest jugador i li va arrancar literalment la bandera de damunt, en una acció que només tenia la pretensió de complir la norma federativa, però que va donar una imatge pitjor que la que es volia evitar. Les xarxes socials i els mitjans de comunicació van tractar durant uns quants dies la qüestió, amb no poca polèmica (Ginés Meléndez va ser trending topic a Twiter). Queda clara, doncs, la importància dels símbols i el paper dels esports de masses com a vehicle per a generar fidelitats, però també per a provocar reaccions de rebuig. Lús de la bandera espanyola va en augment i l'esport (i més concretament el futbol) ha tingut un paper rellevant per a fer un pas més enllà, però en qualsevol cas, s'ha d'estar pendent de les conjuntures i s'ha de veure si un ús abusiu d'aquesta bandera pot generar també un rebuig major per part dels nacionalismes subestatals, més encara quan, en el cas de Catalunya, es viu un procés sobiranista.

En aquest sentit cal entendre, finalment, les declaracions del senador per EAJ-PNV Iñaki Anasagasti en el seu bloc l'endemà de la victòria en l'Eurocopa, 
quan deia que s'havia fet més evident que mai que existeix un nacionalisme espanyol:

¿Quién es el que dice que el nacionalismo español no existe? Existe y se manifiesta. Y no es malo. Es malo que lo oculten. Es el mismo nacionalismo que niega en el Parlamento Vasco una consulta en nombre de su nacionalismo y es el mismo nacionalismo que llena la plaza de Colón y da bocinazos porque España gana la Eurocopa ${ }^{16}$.

I continuava contestant als atacs que s'havien produit des dels mitjans de comunicació del centre principalment contra el president de l'Euskadi Buru Batzar Íñigo Urkullu, que havia declarat en la ronda de semifinals que, com que no hi jugava Euskadi, preferia que guanyara Rússia, ja que el joc d'aquest equip era el que més li agradava. Rússia va ser derrotada precisament per Espanya, i des de mitjans com la COPE o El Mundo es va aprofitar per a atacar durament Urkullu i fer-ne burla ${ }^{17}$.

\section{UNA APROXIMACIÓ EMPÍRICA: SENTIMENT NACIONAL I SELECCIÓ ESPANYOLA EN ELS MILITANTS VALENCIANS DE PARTITS D'ESQUERRA I CENTREESQUERRA}

Tenint com a referència el que hem comentat sobre la selecció espanyola i el que ha aportat a l'enfortiment del sentiment nacional (espanyol), dins d'una investigació centrada en els discursos sobre la identitat territorial entre els militants valencians d'organitzacions polítiques d'esquerra i centreesquerra, hem volgut arreplegar el discurs parcial sobre els triomfs de la selecció espanyola, l'actitud cap a aquests triomfs i cap a la seua celebració amb profusió de símbols nacionals espanyols ${ }^{18}$. Les seleccions nacionals esportives són una vivència nacional per

${ }^{16}$ http://ianasagasti.blogs.com/mi_blog/2008/06/cualquiera-les-aguanta.html (publicat el 30 de juny de 2008; visita el 18/11/2013).

17 Segons refereix Anasagasti, «El Grup Risa [sic], de la COPE, ha llegit un informe mèdic des de Cruces en què, segons sembla, està ingressat Iñigo afligit de forts dolors gàstrics des del moment en què va escoltar el coet del gol de Torres. Han dit que va estar a punt de "palmar-la" i reunir-se amb Sabino Arana en el més enllà i que seguirà en observació fins que la Selecció hispana passe per Colón i se’n vaja de vacances. Sembla ser que Puigcercós deu estar en la mateixa, però no ha perdut el coneixement perquè, segons diuen, mai n'ha tingut». Anasagasti també cita textualment un article de Pedro J. Ramírez en El Mundo: «Què ridículs resulten des de tals altures [les de la victòria d'Espanya] les pretensions dels Ibarretxe, Urkullu, Erkoreka, Puigcercós, Carod i altres pigmeus als quals els amarga la vida els triomfs esportius que, en definitiva, reflecteixen la puixança internacional d'Espanya, fruit de l'èxit de la nostra democràcia constitucional!» (vegeu el mateix bloc citat en el peu de pàgina anterior).

${ }^{18}$ La investigació va ser desenvolupada amb finançament parcial de la Fundació Jaume Bofill. El treball de camp és va fer en la segona meitat del 2011, quan ja s'havien produit els triomfs a l'Eurocopa 2008 i la Copa Mundial de Futbol del 2010. 
a tots els ciutadans, se senten o no de la nació concreta (en aquest cas, l'espanyola) i, per tant, seguint els arguments de Billig (2006), contribueixen a la incorporació d'un afecte que en molts casos se sobreposa a les filiacions nacionals explícites. Com que el treball de camp volia captar els discursos sobre la identitat territorial al País Valencià entre els militants d'esquerra i centreesquerra, i partíem de la possibilitat (després confirmada) que molts d'ells evitarien definir-se explícitament com a espanyols pels prejudicis que encara persisteixen entre la militància d'esquerres (Taibo, 2007: 27) -i més si hi ha un valencianisme sobiranista-, vam incorporar la possibilitat de captar afectes indirectes, en aquest cas a través de les seleccions nacionals esportives, i més específicament la de futbol. Siga per la presència continuada d'Espanya com a "nació banalitzada" (Billig, 2006), o per altres mecanismes que permeten l'adhesió a un combinat de jugadors de futbol, consideràvem que podia aparèixer en aquests militants una adhesió a la selecció nacional d'Espanya, i un discurs de justificació d'aquest discurs, en tant que prèviament se'ls havia demanat l'explicitació del seu sentiment nacional (espanyol, valencià, català).

\subsection{Consideracions metodològiques}

Hem desenvolupat una investigació qualitativa basada en entrevistes semiestructurades a militants de base de tres organitzacions polítiques d'esquerra i centreesquerra: Bloc, EUPV i PSPV-PSOE. El mostreig qualitatiu per quotes s'ha fet a partir de les variables organització política i comarca. En el primer cas es pretenia que tingueren presencia els partits d'esquerra i centreesquerra ${ }^{19} \mathrm{amb}$ més implantació en el territori valencià, per a garantir una militància heterogènia en cadascun dels segments. Precisament perquè cada segment sorgeix de la combinació entre les dues variables (organització política i comarca) i, per tant, havíem de comptar amb una representació notable de cada partit en cada comarca, per a poder obtenir una mostra variada atenent a un altre tipus de característiques sociodemogràfiques (sexe, edat, professió, nivell d'estudis, etc.) i evitar així biaixos associats a la sobrerepresentació d'alguna variable.

I quant a la variable territorial, la comarca on milita, se n'han seleccionat també tres (l'Alacantí, l'Alcoià-Comtat i l'Horta de València), entenent que si es tractava de disposar d'una petita mostra per segment, nou (tres comarques per tres formacions polítiques) ja és una xifra elevada de segments per a un treball de camp en el qual es garantia un mínim de cinc entrevistes per cadascun (la diversitat de discursos ha motivat l'increment en uns quants d'ells fins a un total de 58 entrevistes).

${ }^{19}$ Que són els que podríem enquadrar, més o menys clarament i tradicionalment, en el valencianisme d'arrel fusteriana, que defensa sense fissures la unitat lingüística. 
Deixant de banda que som conscients que hauria sigut interessant incorporar altres comarques i que en la mostra final ha condicionat la necessitat de delimitació, les tres comarques seleccionades ho són en la mesura que representen diferents maneres d'entendre la identitat valenciana en els termes plantejats per Piqueras (1996), perquè l'objecte principal de la investigació era el discurs que aquests militants fan de la identitat territorial. L'Horta (València i el seu hinterland) seria el cor d'una identitat valenciana més intensament afirmada com a distintiva respecte de la hipotètica unitat amb Catalunya i, en conseqüència, on més ha d'haver arrelat el particularisme valencià. Alacant i la seua àrea d'influència són històricament les que més han contestat la identitat valenciana i alguns sectors han plantejat una identitat alternativa, de tipus cantonal/provincial, però molt aferrada a la idea d'Espanya (vegeu Piqueras, 1996: 217-230). Finalment, la comarca de l'Alcoià-Comtat té en la història contemporània el protagonisme d'Alcoi com a nucli industrial potent dins del context valencià, i amb uns vincles forts amb Catalunya a través de l'especialització tèxtil. El desenvolupament industrial alcoià (i el subsegüent moviment obrer), en paral-lel al català, va motivar que s'arribara a denominar Alcoi la Barceloneta valenciana. Com deien Mollà i Mira, «Barcelona havia estat sempre [...] punt de referència; [...] l'eix Alcoi-Terrassa tènia una certa tradició» (1986: 114-115). Això ha tingut també derivades en l'àmbit arquitectònic, amb la presència d'un apreciable modernisme a Alcoi, i una efervescència cultural dependent en altres temps de Barcelona. D'altra banda, a la capital de l'Alcoià sorgeix el model de festa de moros i cristians que més s'ha estès (vegeu Alcaraz, 2006) i que, des de fa més d'un segle, fa molt visible la Reconquesta catalanoaragonesa i el vincle amb Catalunya. Per tot això, es pot esperar que el fusterianisme i l'aposta pel marc territorial Països Catalans s'hi mantinguen més presents que en altres comarques.

En qualsevol cas, tot i alguna referència a aquests segments, els discursos sobre els èxits de la selecció espanyola i la posterior exhibició simbòlica es tractaran globalment i, sobretot, en relació amb el sentiment nacional dels entrevistats.

\subsection{Sentiment nacional i el discurs sobre la victòria de la Roja}

En la interacció amb els entrevistats, es preguntava a tots si s'alegren pels triomfs que està aconseguint l'esport espanyol, especialment la selecció de futbol, i la major part d'aquests militants se n'alegra. En el cas del PSPV-PSOE són quasi tots els entrevistats, i ho fan pràcticament sense titubejos ni aclariments. Per la seua banda, en EUPV també són una majoria considerable, però una part d'ells afegeix diferents matisos a aquest sentiment i els que no se n'alegren són també 
una part a tenir en compte. Finalment, en el Bloc trobem un major pes de respostes negatives i d'indiferents que en els altres partits, però també dominen els que s'alegren dels triomfs dels esportistes espanyols, especialment per les respostes afirmatives a l'Alcoià-Comtat, que compensen el domini dels que no s'han congratulat d'aquestes victòries entre els nacionalistes de l'Horta i de l'Alacantí.

Quan es produeix la resposta afirmativa amb matisos, normalment es tracta de militants que anteriorment han manifestat que no se senten espanyols o que, en cas afirmatiu, també havien aportat determinades explicacions a aquest sentiment. Per tant, se senten en la necessitat de justificar per què s'alegren per la victòria de Nadal, Alonso o la Roja. I les argumentacions van en el sentit que es produeix una alegria collectiva que pot estar bé en aquests temps de crisi; que són jugadors (els de la selecció espanyola de futbol) que senten més propers perquè estan en (o han sorgit de) la Lliga espanyola i se'ls ha seguit més; perquè l'eix central de l'equip són jugadors del Barça i també la filosofia de joc i, en aquests casos, l'entrevistat és aficionat del Futbol Club Barcelona (i normalment professa un valencianisme catalanista); o, senzillament, perquè «juguen bé». Es tracta, en qualsevol cas, de descartar l'argument nacional, de deixar clar que l'alegria o la satisfacció no està motivada per una adhesió als colors d'Espanya o a la nació espanyola. I aquesta és una posició més típica dels afiliats d'EUPV:

M'alegre dels triomfs de la selecció, més de la de bàsquet que de la de futbol, també potser perquè m'agrada més aquest esport, però també per connotacions ideològiques. La selecció de futbol sembla que tinga més el tarannà que és la bandera d'una Espanya «casi grande, casi Roja i casi libre» (això de roja per la samarreta només). Però bé, te n'alegres perquè ho comparteixes, bàsicament per allò que té conviure, convius amb la gent, comparteixes; a la gent la veus alegre, doncs tu també te n’alegres... Tot i que també t’adones del ridícul que hi ha darrere del fanatisme del futbol i del món del futbol, però bé (EUPVAlcoià-5, 47:41).

Sí que me n'alegre, no sé, depèn, perquè com deia el meu fill, la selecció espanyola de futbol estava composta per jugadors del Barça, sobretot i fonamentalment; en els últims campionats, en l'últim mundial, crec que el percentatge més gran de jugadors era del Barça, o siga que... Sí, és la selecció espanyola, però són els jugadors del Barça els que estaven al darrere (Bloc-Horta-2, 36:11).

Sobre la base dels que estan satisfets amb les victòries esportives espanyoles, aquest ja és un avanç de les motivacions d'aquesta satisfacció, però centrat en aquells que plantejaven algun dubte o, si més no, una satisfacció relativa. Però la majoria de les motivacions per aquesta alegria apunten a l'argument nacional, al fet que aquests esportistes representen la que és reconeguda com a nació pròpia: 
De l'esport només m'agrada la selecció espanyola de futbol. M'alegre quan guanyen i m'agrada veure els partits. [...] M'ha agradat sempre. Jo el futbol no l'entenc molt, però quan juga Espanya m'agrada veure'l. [...] Quan guanya, superbé; aquests anys està sent massa! Vull que guanye perquè jo sóc espanyola (PSPV-Alcoià-2, 29:46).

M'alegre i gaudisc dels triomfs de la selecció espanyola, preferisc que la selecció espanyola guanye davant qualsevol altre combinat estranger i em sent identificat amb Fernando Alonso, amb Nadal, amb Pau Gasol i amb qualsevol espanyol. [...] Jo crec que és una alegria compartida; són ciutadans d'aquest país i com a tals m’alegre que els vagen bé les coses. I, a més, també perquè és gent jove, preparada, que s'esforça i d'un determinat perfil; i si tenen èxit, jo crec que és motiu d'alegria. [...] No hi ha altra opció que alegrar-se, perquè els sentim com a propis, independentment que siguen valencians, bascos, madrilenys o asturians. Aleshores, a què és degut? Doncs que ho entenem com una cosa nostra, com a allò propi, i que un espanyol triomfe en el món, «nos llena de orgullo y satisfacción», com diria el rei (PSPV-Horta-2, 50:45).

De tota manera, aquesta motivació és característica dels militants del PSPVPSOE (sobretot de l'Alacantí i l'Horta) i alguns d'EUPV, però no cap del Bloc, que quan s'alegren de les victòries de la selecció espanyola de futbol, ho fan sobretot perquè, com hem vist amb l'entrevistat número 2 del Bloc de l'Horta, associen la selecció al Barça (en el Bloc trobem la major proporció de culés entre els militants d'esquerra i centreesquerra) o perquè senten els jugadors espanyols més propers que altres, en el benentès que compartir estat (i lliga de futbol) genera un sentit de pertinença que, en aquest cas, no es vincula al sentiment nacional: «Jo m'alegre que un conjunt de jugadors que juguen una lliga aconseguisquen un títol, un trofeu. És la lliga que jo seguisc, és la més propera. Si digueres "vols una lliga pròpia?", (...) és possible, però no és el cas» (Bloc-Alcoià-2, 41:19).

En qualsevol cas, el que s'ha comprovat amb aquest apartat és que els esportistes espanyols, i més concretament la selecció espanyola, generen un sentiment d'adhesió fins i tot en gent que no se sent espanyola, siga pels vincles amb el Barça, per la proximitat, perquè juguen bé..., però el cas és que bona part dels que havien apuntat que no se senten espanyols s'han alegrat dels triomfs en l'Eurocopa i el Mundial. I això com a mínim significa que el rebuig categòric a la idea d'Espanya és marginal en aquests partits - sense oblidar que aquí hi ha una diferència clara entre el PSPV (completa adhesió a la selecció i vinculada al sentiment espanyol) i el Bloc (adhesió més condicionada)-. Per tant, els èxits esportius estan contribuint a propiciar afectes fins i tot sobreposant-se a la filiació nacional explicitada. La inclusió en l'estudi dels independentistes ERPV o PSAN (descartats per les complicacions d'abordar una mostra per 
quotes tal com havíem plantejat) hipotèticament hauria propiciat altres resultats, més en la línia del rebuig als representants de la nació espanyola, en contrast amb l'absència de maximalisme nacional en la línia política pública del Bloc.

\subsection{L'exhibició de la bandera en els triomfs de la selecció espanyola de futbol}

En aquest cas es tractava d'obtenir i analitzar els discursos de la militància valenciana d'esquerra i centreesquerra sobre el sobtat ús massiu de la bandera d'Espanya a partir de les victòries de la selecció de futbol. Concretament s'ha preguntat què els semblava l'increment de l'ús de la bandera espanyola arran d'aquests triomfs fins al punt d'un ús que es podria qualificar de massiu (especialment en relació amb la situació anterior, quan semblava que hi havia prejudicis que impedien fer el pas d'exhibir la rojigualda amb normalitat). Hem trobat una gran varietat de respostes, però dominen els entrevistats als quals no els ha agradat aquesta presència sobtada del símbol espanyol a les façanes, cotxes i carrers del País Valencià i de la resta de l'estat. De tota manera, les diferències per partit són aquí molt acusades i, per tant, anem a aturarnos en aquesta variable de segmentació, que acompanyarem amb les explicacions que els entrevistats han fet sobre el seu grau de satisfacció.

En el PSPV-PSOE dominen els que es van alegrar d'aquesta exhibició patriòtica, tot i que també hi ha una part important d'indiferents. El que a penes trobem són militants als quals no els va agradar la presència de banderes espanyoles després de les victòries. Però centrem-nos en els que sí que se'n van alegrar, que és el sentiment majoritari en els entrevistats del PSPV-PSOE. Aquests militants estaven satisfets per l'ús massiu de la bandera, sobretot perquè implicava la normalització d'aquest símbol i que deixara de ser un monopoli de la dreta. En certa mesura, s'ha sentit com el trencament d'un prejudici (el que associava la rojigualda al nacionalcatolicisme franquista), que impedia la normalitat i l'homologació a altres estats democràtics que exhibeixen la seua ensenya sense problemes. En molts casos, s'assenyala la marca «Gobierno de España» de Rodríguez Zapatero com una primera intenció política en aquest sentit, però el futbol ha fet el pas definitiu:

Jo crec que això ha normalitzat un poquet el tema dels símbols nacionals i els ha llevat una miqueta aquest nacionalisme ranci, antic, franquista. D'alguna manera, hem rescatat mitjançant l'esport $i$ aquests èxits a Europa $\mathrm{i}$ al món [...] els símbols nacionals. Se suposa que totes les comunitats estem sota aquest símbol general, i d'alguna manera el personal l'ha fet seu. Aquest rebuig de moltes zones, perquè venia imposat i [...] excloïa els símbols valencians o catalans o del País Basc o d'on fóra, doncs, en aquest moment sembla que s'ha rescatat 
un poquet i és perfectament compatible: un pot ser català i, a més, quan guanya Espanya, alegrar-se, no se n'ha d'amagar. [...] Sí, d'alguna manera ha normalitzat això; aquestes coses, si les mires en positiu... I ha sigut un mèrit de la gent en general no permetre que les faccions més feixistes i més nacionalistes espanyoles s'apoderaren d'això. [La població] ha furtat un poc a aquesta gent el símbol; i al PP també, amb aquest apoderament que feien de la bandera i dels colors. [...] També Gobierno de España amb els colors ha sigut un treball en aquest sentit, s'ha fet molta pedagogia d'aquest aspecte; jo crec que ha sigut un encert. És el que ens falta fer a nosaltres ací; el PP [...] al País Valencià s'ha fet l'amo dels símbols, i com que nosaltres encara estem així que ens fa un poc d'angúnia el blavet i no sé què, [...] t’impedeix apoderar-te d'això i fer-ho teu, perquè t'ho han imposat i encara et queda així... (PSPV-Horta-1, 1:09:20).

[Va estar] molt bé, molt bé. Ací es va veure que aquestes diferències que tantes vegades volen marcar-nos més de quatre realment no existeixen. És tot un interès polític per a obtenir quatre vots, i no el que realment la ciutadania pensa. Crec que la gent no és tan visceral com sembla. Ens sentim tots molt orgullosos d'haver nascut en aquest país en el qual vivim. [...] El problema és que la dreta fa mal ús de certes coses, entre altres, la bandera, i aleshores jo crec que ací [...] la gent no en va fer un ús identificat amb la dreta. [...] [La bandera] no pertany a un grup o un altre, la bandera és de tots els espanyols. El que van fer els espanyols és sentir-se identificats i orgullosos. Fins a aquest moment, molta gent, perquè no els identificaren amb la dreta, no en feia ús, però, vaja, pense que això és patrimoni de tots els espanyols, no d'un partit polític en concret. Això ja va passar fa molts anys i la gent que intenta que això continue sent així està molt equivocada (PSPV-Alcoià-1, 37:36).

Per la seua banda, els militants del PSPV-PSOE que s'han mostrat indiferents davant d'aquesta exhibició patriòtica lligada al futbol atribueixen aquest fenomen a una mostra d'alegria sense cap més consideració de tipus polític o politiconacional.

En el cas d'EUPV, tenim la major varietat de respostes, però dominen aquells als quals no els va agradar l'ús massiu de la bandera i els indiferents. Respecte d'aquests darrers i el grup que va veure de relatiu bon ull l'exhibició de l'ensenya, es reparteixen entre explicacions com la que sol fer la militància del PSPV-PSOE ( «va ser la normalització de l'ús de la bandera»; «ja no és monopoli de la dreta») i atribuir el fenomen a una combinació d'alegria i nacionalisme espanyol:

A mi [les façanes plenes de banderes] no em causaven mala sensació ni rebuig, perquè entenia que és un moment de felicitat colllectiva, tot i que és trist que el futbol siga un moment de felicitat col-lectiva, però bé, és així, i és un element que uneix molt la gent; però també vaig entendre que s'estava aprofitant molt 
el moment per a fer un altre tipus de reivindicació per darrere que no tocava. Els polítics feien declaracions en un doble sentit: estem molt contents que Espanya siga la campiona i tal, però també «això demostra que Espanya és un poble unit!, porque España junta...» i ja el plumero se'ls veia a distància (EUPVHorta-1, 52:07).

Però a Esquerra Unida, com hem apuntat abans, la sensació dominant era la de rebuig a aquest ús massiu de l'ensenya espanyola, siga des d'una òptica internacionalista o valencianista, perquè se'n va fer una lectura en termes d'exaltació patriòtica espanyola:

Home, pense que estratègicament van ser utilitzats per la dreta. Clar, això dut a una població que està demostrat que no té una cultura [política] molt potent, per dir-ho d'alguna manera, doncs en l'euforia tothom entra en el joc. Pense que ací la dreta s'ho va muntar molt bé per a promocionar el nacionalisme espanyol. I de pas, com en la selecció un percentatge prou gran dels jugadors eren de Catalunya i del Barça, doncs era una manera de tocar els nassos un poquet. Segurament la majoria dels que anaven pel carrer no es muntaven aquesta historieta, ho feien de manera totalment natural, però pense que «la mà que tot ho domina» estava darrere (EUPV-Horta-5, 36:25).

Jo [tot això de la bandera ho vaig viure] fatal, fatal. [...] Ja no és que la gent s'ho fique en el balcó, és que alguns plantaren un pal amb una bandera i dic, sort encara que ací [al meu edifici] no n'han posat cap, perquè si no, vaja, jo em queixe a la [comunitat de veïns]. Era molt... no sé, semblava que estaves ací en... jo no he viscut el franquisme, però semblava que estaves en aquells temps i només faltava que alçares el braç per a trobar-te «com a casa». No sé, no em va agradar molt, la veritat. Jo sí que associe l'ús de la bandera espanyola [...] amb el feixisme, aleshores, en aquest sentit [...] la bandera espanyola [...] ha sigut un poc la bandera amb la qual s'ha massacrat la meitat del país i són unes ferides que no s'han tancat ni es tancaran mentre no es vullga recuperar un poc la memòria. [...] És veritat que molta gent no utilitza la bandera d'aquesta manera tan conscient, no tots són fatxes en realitat, especialment la gent jove, però a mi em molesta (EUPV-Horta-2, 55:27).

Finalment, en el Bloc hi ha un rebuig quasi complet a aquesta profusió dels símbols espanyols després dels triomfs esportius i, tot i que alguns entenen que havia un component de manifestació d'alegria, en general consideren aquells moments una exaltació nacionalista espanyola en els termes que ja hem vist en els discursos d'Esquerra Unida:

A mi, veure totes les banderes espanyoles pels balcons, això em feia posar-me molt, molt malament. I gent que la va tenir tot l'any quasi! De seguideta tenien l'excusa, i treien el pitjor que tenien dins els espanyolets aquests que són molt radicals, fatxes. Això sí que em feia ràbia que ho tragueren en aquests moments (Bloc-Alcoià-3, 24:13). 
[Com a primera resposta mostra el llibre de Michael Billig (2006) que s'ha llegit fa poc i té a mà]. Això, Nacionalisme banal, és a dir, és això: els que acusen de nacionalisme són els més nacionalistes, i ja està. I no és gratuit i saben el que fan; estan en la construcció de la seua nació, que és Espanya, i que a més és uniformitzadora i intenta aniquilar la resta de diversitat i riquesa [cultural] de l'estat. Ho vaig veure com una exaltació nacional espanyola i em va causar rebuig (Bloc-Horta-3, 42:47).

El matís de confrontació de projectes nacionals és potser el que pot distingir el patró de respostes d'EUPV del tipus d'arguments dels militants del Bloc: per a la militància del Bloc l'exhibició dels símbols espanyols o d'espanyolisme és fer evident el nacionalisme d'estat que impedeix exercir les llibertats nacionals dels valencians $i$, en aquest sentit, el rebuig ha tingut moltes vegades aquesta connotació de lluita nacional.

\section{BALANÇ}

La darrera cita del militant del Bloc de l'Horta torna a introduir un dels referents més importants en la investigació sobre el nacionalisme, Michael Billig i el seu Nacionalisme banal (2006), i això ens serveix per a iniciar aquest balanç considerant que l'esport també contribueix a la banalització de les nacions a través dels campionats (estatals, però, en definitiva, nacionals), que se'ns representen amb una familiaritat tal, que arriben a permetre una identificació fins i tot entre aquells que no se senten membres de l'àmbit nacional que abasta el torneig. Així, hem pogut comprovar que, fins i tot alguns militants nacionalistes i afiliats de partits d'àmbit estatal que se senten més valencians que no pas espanyols, arriben a sentir com a propi el triomf de la selecció espanyola, perquè els components d'aquest combinat els senten més propers, són més recognoscibles, juguen en una lliga que segueixen més que altres o, fins i tot, són en gran mesura integrants del Barça, que és el seu club favorit. Tot això arriba a sobreposar-se a la filiació nacional explicitada prèviament, sense que intervinga de manera decisiva la dinàmica mateixitat-alteritat, és a dir, el fet de sentir-se nacionalment valencians, que s'hauria de contraposar a una espanyolitat aparentment no sentida, no implica un rebuig absolut a aquesta representació esportiva de la idea d'Espanya.

Això sí que succeiria, però, amb l'independentisme catalanista present en terres valencianes, perquè aquesta posició sí que implica una impugnació més explícita d'Espanya, que no pas el valencianisme del Bloc, que s'ha revisat per a adaptar-se al sentiment dels valencians i la seua dominant «identitat dual» (vegeu Coller i Castelló, 1999), que compatibilitza de manera no traumàtica la valencianitat i l'espanyolitat. I si això succeeix amb alguns militants del Bloc, 
més encara amb els de partits d'obediència estatal, especialment el PSPV-PSOE, que precisament reivindica aquesta identitat dual, però també EUPV, que, tot i l'internacionalisme i que, en certa mesura, fuig de la idea (nacional) d'Espanya encara influït pels prejudicis de dècades de dictadura nacionalcatòlica (Núñez, 2007: 159), el seu projecte és de marc espanyol.

En definitiva, a partir del que s'ha vist en el treball de camp, l'absència d'alegria pels triomfs de la selecció espanyola de futbol entre els militants d'esquerra i centreesquerra ha aparegut entre els que no els agrada l'esport (i menys el futbol), però també els de posicions més sobiranistes i més catalanistes (no sempre lligades), que, en tot cas, han sigut minoria, però suggereixen que la impugnació a la idea d'Espanya en terres valencianes continua lligada a la consideració del marc Països Catalans. Una altra qüestió és l'exhibició de les ensenyes nacionals espanyoles, que és una actuació que ha provocat més rebuig, llevat de la militància del PSPV-PSOE, que identifiquen en aquest fet una esperada normalització dels símbols, en el context d'aquest patriotisme constitucional impulsat des de l'esquerra i reivindicat hàbilment després per la dreta (Núñez, 2007: 160 i 170-173; vegeu també Sternberger, 2001).

\section{BIBLIOGRAFIA}

Adán, Teresa (2004). «Ultras. Culturas del fútbol». Estudios de Juventud, 64, 87-100.

Alcaraz, Albert (2006). Moros i cristians. Una festa. Picanya (València): Edicions del Bullent.

Anderson, Benedict R.O. (1993). Comunidades imaginadas. Reflexiones sobre el origen y la difusión del nacionalismo. Mèxic D.F: Fondo de Cultura Económica.

Arnaud, Pierre (1991). «Dividing and uniting: sports societies and nationalism, 18701914». A Robert Tombs (editor), Nationhood and nationalism in France: from Boulangism to the Great War, 1889-1918. Nova York (EUA): Routledge, 182-194.

Bairner, Alan (2001). Sport, nationalism, and globalization. Albany (Nova York, EUA): State University of New York Press.

Billig, Michael (2006). Nacionalisme banal. Catarroja (València): Afers-Universitat de València.

Coller, Xavier i Rafael Castelló (1999). «Las bases sociales de la identidad dual: el caso valenciano». REIS, 88, 155-183.

Colomé, Gabriel (2007). «Una nota sobre deporte y política». A Carlos Taibo (dir.), Nacionalismo español. Esencias, memoria e instituciones. Madrid: Los Libros de la Catarata, 377-382.

Dekker, Henk; Darina Malová i Sander Hoogendoorn (2003). «Nationalism and its explanations». Political Psychology, 24 (2), 345-376.

Díaz Noci, Javier (2000). «Los nacionalistas van al fútbol: deporte, ideología y periodismo en los años 20 y 30». Zer-Komunikazio Ikasketen Aldizkaria, 9. 
Finn, Gerry P.T. i Richard Giulianotti [eds.] (2000). Football culture. Local contests, global visions. Londres (Anglaterra): Frank Cass Publishers.

Gellner, Ernest (1998). Nacionalisme. Catarroja (València): Afers.

González-Ramallal, Manuel E. (2008). «La identidad contada: la información deportiva en torno a la selección española de fútbol». Universitas Humanística, 66, 219-238.

Hobsbawm, Eric J. (1992). Naciones y nacionalismo desde 1780. Barcelona: Crítica.

Letamendia, Francisco (1997). Juego de espejos. Conflictos nacionales centro-periferia. Madrid: Trotta.

Llopis, Ramón (2007). «Identity, nation state and football in Spain. The evolution of nationalist feelings in Spanish Football». Soccer \& Society, 9 (1), 56-63.

Llopis, Ramón (2006). «Clubes y selecciones nacionales de fútbol: la dimensión etnoterritorial del fútbol español». Revista Internacional de Sociología, 45, 37-66.

Maguire, Joseph (1999). Global sport: identities, societies, civilizations. Cambridge (Anglaterra): Polity Press.

Medina, Federico (2009). «El fútbol y la vivencia festiva de la nacionalidad». Razón y Palabra, 69.

Mollà, Damià i Eduard Mira (1986). De impura natione. El valencianisme, un joc de poder. Valencia: Tres i Quatre.

Naranjo, Alicia (2011). Tratamiento de la información deportiva en la prensa: la crónica como género prevalente. El caso de los encuentros de fútbol entre el Real Madrid y el FC Barcelona. Málaga: Universidad de Málaga (tesi doctoral).

Núñez, Xosé M. (2007). «Conservadores y patriotas: el nacionalismo de la derecha española ante el siglo XXI». En Carlos Taibo (dir.), Nacionalismo español. Esencias, memoria e instituciones. Madrid: Los Libros de la Catarata, 159-192.

Payero, Lucía (2009). «La nación se la juega: relaciones entre el nacionalismo y el deporte en España». Ágora para la Educación Física y el Deporte, 10, 81-117.

Piqueras, Andrés (1996). La identidad valenciana. La difícil construcción de una identidad colectiva. Madrid: Escuela Libre Editorial-Edicions Alfons el Magnànim.

Plaza, Diana (2009). «La construcción discursiva de la nación a través del fútbol. Un discurso social de éxito». Prisma Social, 2, 21 pàg.

Robertson, Roland i Richard Giulianotti (2006). «Fútbol, globalización y glocalización». Revista Internacional de Sociología, LXIV (45), 9-35.

Rogers, Gary i Joel Rookwood (2007). «Cardiff City Football Club as a vehicle to promote Welsh national identity». Journal of Qualitative Research in Sports Studies, 1 (1), 57-68.

Santacana, Carles (2005). El Barça i el franquisme. Crònica d'uns anys decisius per a Catalunya (1968-1978). Barcelona: Mina.

Seco, Carlos (2011). «El Celtic FC y la expresión del republicanismo a través de los cánticos de fútbol». Oceánide, 3, 6 pàg.

Shobe, Hunter (2008). «Place, identity and football: Catalonia, Catalanisme and Football Club Barcelona, 1899-1975». National Identities, 10 (3), 329-343. 
Sopena, Jordi; Xavier Ginesta i Cristina Pozo (2008). «Identidad y medios de comunicación deportivos en España. El éxito de la selección de baloncesto en el Campeonato del Mundo de Japón 2006». RUTA-Revista Universitària de Treballs Acadèmics, 1,25 pàg.

Sternberger, Dolf (2001). Patriotismo constitucional. Bogotà (Colòmbia): Universidad Externado de Colombia.

Szabó, Róbert G. (2012). «Identity and soccer in Corsica». Soccer and Society, 13 (1), 36-55.

Taibo, Carlos [dir.] (2007). Nacionalismo español. Esencias, memoria e instituciones. Madrid: Los Libros de la Catarata.

Young, Christopher (2005). «When Pierre met Adolf? The Olympic Games in the age of technical reproduction». Conference on Globalization and Sport in Historical Context. San Diego: University of California, març, 36 pàg.

LLUÍS CATALÀ OLTRA es doctor en Sociologia per la Universitat d'Alacant, i professor associat del Departament de Sociologia II de la mateixa institució des de l'any 2000. En el terreny professional, és Coordinador de Projectes de CIDES Estudios de Mercado des del 1998. Les seues línies d'investigació inclouen la identitat territorial, el nacionalisme, la sociolingüística i l'impacte socioeconòmic de les infraestructures i les actuacions sobre el territori.

Recibido: $24 / 07 / 2013$

Aceptado: 27/11/2013 